\title{
Study of Crevice Corrosion Behavior and Cathodic Protection of Carbon Steel Reinforcement in Concrete
}

\author{
Jiuquan Chen, Lingfeng $\mathrm{Ji}^{*}$, Jinwei Song \\ Hebei Construction Material Vocational and Technical College, Qinhuangdao 066004, China \\ *E-mail: teacher_ji1234@163.com
}

Received: 3 September 2021 / Accepted: 19 October 2021 / Published: 6 December 2021

\begin{abstract}
Chloride ion ingress is one of the critical factors causing concrete failure in structures. Cathodic protection is widely used in concrete for corrosion protection as it promotes interface alkalization and removes chloride ions. However, some positions are in an over-protected state due to cracks in concrete, especially at the concrete-reinforcement interface. Therefore, based on immersion and electrochemical experiments, this paper evaluates the optimal cathodic protection potential of reinforcement under different temperatures through corrosion rate, morphology, and electrochemical parameters, and the electrochemical characteristics of the metal at the opening under the condition of optimal cathodic protection potential. The results showed that with the increase of cathodic protection level, HRB335 steel exhibited a general corrosion state at $20^{\circ} \mathrm{C}$. However, the corrosion state changed from pitting to comprehensive corrosion at $50^{\circ} \mathrm{C}$ and $80^{\circ} \mathrm{C}$, and the oxygen diffusion process controlled the optimal cathodic protection potential. Considering the corrosion rate, morphology, and electrochemical reaction control process, the optimal cathodic protection potential was $-1.0 \mathrm{~V}$ and $-1.1 \mathrm{~V}$ at $50^{\circ} \mathrm{C}$ and $80^{\circ} \mathrm{C}$, respectively. Meanwhile, when the HRB335 steel in the deepest crevice reached the optimal cathodic protection potential, the metal in the opening may be in an over-protected state, and a hydrogen evolution reaction occurred. The higher the temperature, the higher was the metal potential and the more pronounced was the hydrogen evolution reaction.
\end{abstract}

Keywords: Reinforced concrete; Corrosion potential; Cathodic protection; Concrete deterioration

\section{$\underline{\text { FULL TEXT }}$}

(C) 2022 The Authors. Published by ESG (www.electrochemsci.org). This article is an open access article distributed under the terms and conditions of the Creative Commons Attribution license (http://creativecommons.org/licenses/by/4.0/). 